\title{
セレンの基礎的研究(第 5 報 $)^{*} \mathrm{X}$ 線廻折線の異常について
}

\section{千早 正 $^{* *}$ 監田信雄 ${ }^{* *}$ 小野崎長英**}

Tadashi Chihaya, Nobuo Shiota and Choei Onozaki : Fundamental Studies on Selenium (5th Report) Anomalous X-Ray Diffraction Lines. In the report, the present writers investigated the crystal growth of selenium by using on X-ray high temperature camera. Two kinds of diffraction lines are observed. One of them changes the position in accordance with temperature and the other does not, and the intensity of the former increases and of the latter decreases with temperature. The crystal of selenium appears to undergo a two-phase transformation and so the former type is called B and the latter A. Vitreous selenium begins to crystallize into B-form in the course of heating as shown in the former report. B-form grows at $140^{\circ}$ and is stable down to the temperature of $70^{\circ}$, but as the state at high temperatures cannot be brought down unchanged to room temperature, it is clear that the B-form is transformed into A-form as the temperature falls.

(Received October 7, 1952)

\section{I.}

第 2 報(1)扣よび第3 報(2)に打いて金虽化ならびに粒子化 處理の加堅處理効果に伴万變化を $\mathrm{X}$ 線的に㷿討したが、今 回は X 線高溫カメラを用いて結晶成長の狀況を觀察した。 結晶成長に關し從來得られた $\mathrm{X}$ 線的測定は種々の處理の 後常溫での測定であり，溳の成長變化括よび格子變化とは 可成り相翼寸る. 前報に招いて解决の $\mathrm{SeA}, \mathrm{B}$ の存在に ついても考察を加える.

\section{II. 宾䮦方法}

前報と同樣 $\mathrm{Fe}$ 特性 $\mathrm{X}$ 線を用い, 高溫カメラは取枠常

** 苂城大學工學部

* 1950 年 9 月本會北海道大會に發表

(1) 本誌, B-14(1950), No.7.

(2) 本誌, B-15(1951), No. 2 .
數 0.259 集注法カメラを用いた. 加熱盟度は室溫，50。， $70^{\circ}, 100^{\bullet}, 120^{\circ}, 140^{\circ}, 190^{\circ}, 200^{\circ}$ で露出前 1 時間その溫度に 保持し 3 時間露出を行つた. 成長の狀況を調べるため引續 き次の段階に溫度を上げ，または下げた場合す检討した。 ガラス狀セレンよりの結晶成長を檢討したかつたのであ るが，結晶化に時間を要し寫阗測定では困難であつたの で，主として一度結晶化して置いたものを處理した.すな わち無加壓で $120^{\circ}, 190^{\circ}$ で處理したもの拉び $120^{\circ}$ で加 厣 $30 \mathrm{~kg} / \mathrm{cm}^{2}$, 處理時間 10 分のもの，怙よびこれをさら に $210^{\circ} 2$ 時閒處理したものを出發點とした.

以上の寫貝測定では笧出に時間を要するため結晶成長の 狀況を連續的に測定することが出來ないので，著者等の製 作した X 線用計數管を周いて豫め寫冥㚘により求めてあ る迴折線の位置に打ける線强或の變化を連緼的に測定し， 經時變化と成長速度抽よび溫度の關聯性を求めた。 


\section{III. 定験結果および考窥}

各試料について Fig. 1, 2,3,4 の如き迴折線を得た. 橫

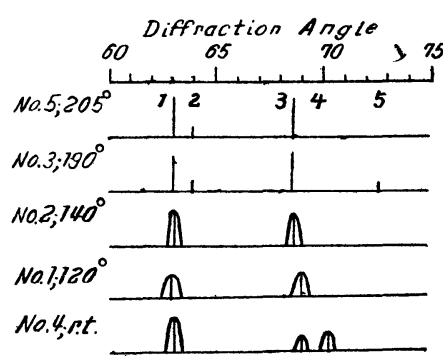

Fig. 1 The Position and Intensity of X-ray Diffraction Lines of Each Sample which Started from Vitreous Se. The First Specimen Heated at $120^{\circ}$.

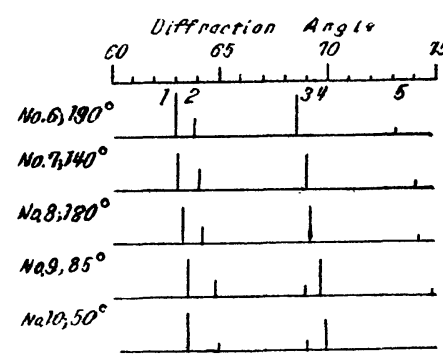

Fig 2 The Position and Intensity of X-ray Diffraction Lines of Each Sample which Started from Vitreous Se. The First Specimen Heated at $190^{\circ}$.

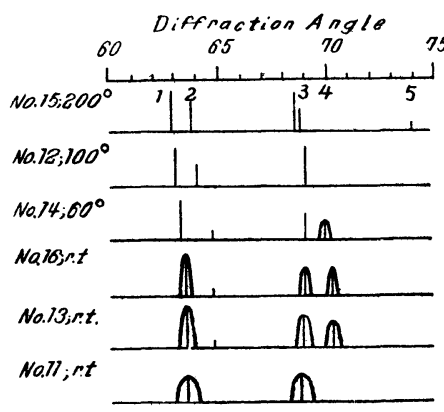

Fig. 3 The Position and Intensity of X-ray Diffraction Lines of Each Sample which Started $f_{1}$ om Crystallised Selenium, Treated at $120^{\circ}$ for 10 min Under the $\mathrm{Pr}$ essure of $30 \mathrm{~kg} / \mathrm{cm}^{2}$.

軸炕迴折角，縱の

線は迴折線の位置 およびその長さは その强度割合を示 し，迴折線つ巾を 圖上でわかり易く するため擴がりの 程度を誇張して袜 す（このウは触 スケールと關係な く，拉の線つ擴 がりの比較を示す に過ぎない).また 同一系列の試料に ついては試料の番 號の順に加熱を行 つたのであるがわ かり易くするため 溫度の順に配列し た. 從つて强度變 化拉よび巾は必ず しも溫度に比例し ていない.この他 に種々の處理を行 つてあるので，履 歴を考慮する必要 がある.

常溫に招いて迴 折角の小さい方か ら迴折線に 1,2, $3,4,5$ 々番號を附 ける. 迴折線 2,4 の位置は圖に示す ように溫度に關係 して變化し溫度上 䄯とらもに迴折角 が小さくなる. 迴 折線 1,3 の位置 はほとんど變化し ない.このよらに 溫度により位置の 變化する 2,4 の 線と, 餘り變化し ない1,3 の線のよ らな2種類の廻折線が見受けられる.これを Fig 5亿示す。 その招互の强度變化を比較すると一方が堆加する時は他 方が減少することから, この場合のセレンの結晶は複相變

化によつて成長するものと考允られる，前者 $(2,4$ の線） を $\mathrm{B}$, 後者 (1,3 の線)を $\mathrm{A}$ と假りに名付けることにする. $30 \mathrm{~kg} / \mathrm{cm}^{2}, 12 c^{\circ}, 10$ 分處理試料 (Fig. 3, No.11) は末

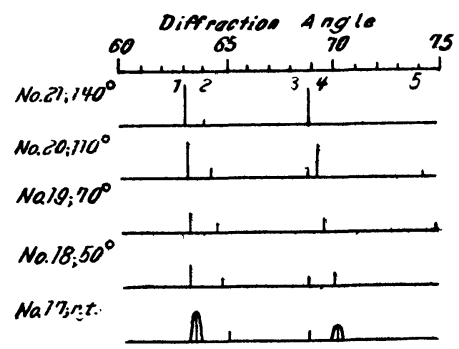

Fig. 4 The Position and Intensity of X-ray Diffraction Lines of Each Sample which Started from Crystallised selenium, Trated at $120^{\circ}$ for 10 min Under the Pressure of $30 \mathrm{~kg} / \mathrm{cm}^{2}$, and then Tretaed at $210^{\circ}$ for $2 \mathrm{hr}$.

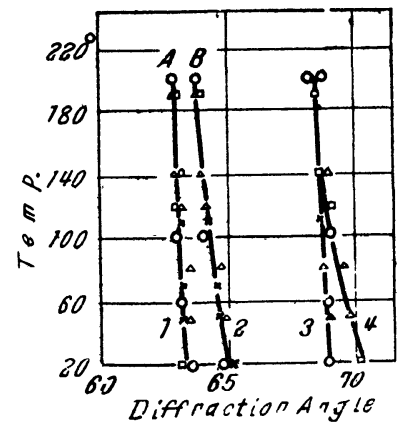

Fig. 5 The Position and Intensity of X-ray Diffraction Line of Each Sample. Fig. 1, Fig. 2, Fig. 3, Fig. 4 .
だ結晶化の始まつ たばかりのもので 1,3 の線だけ，ま たガラス狀から 無加酎で結晶化 さ世る場合 $140^{\circ}$ に上昇させな いもの (Fig. 1, No 1) \& 1,3 の 線だけで，140。 加熱して始めて B が出來來るもの小 如く，2,4 の線か 見受けられるよう になり，14c 加 熱を受けたものは その後窒溫に持ち 來たしても2,4の 線が見受けられ (No 13,4)，溫度 に應じて圓のよう に椢折線の位置の 變化扣よび强度の 變化がある. しか し高温に打ける狀 態をそのま〉室泪 に持ち來たすこと は出來ないで室温 に持いては䢙折角 は大きくなる.し かしその履歷扣上び時間の經過につれてこの位置に變化が あるようである(No. 16, 17).

强度を觀察すると空溫において 3,4の線の强度はほとん ど等しく(No 16,17 など), 高溫で 4 が3より强いこと から (No. 20)，高溫で B が增し A が減ずる.すなわち 140・附近で B が出來て來ると考えられる. しかし室温に 持ち來たすと B は A に變化して行くと考えられる. 電 氣抵抗の測定に招いても高温に特いて結晶化した時の抵抗 は室溫に放置すると漸次䍿加して行く現象が欟察されるこ と〉符合する.

また一度結晶化したものは $70^{\circ}$ 附近で趗折線 5 が見受け られるよらになるが (No.15,9)，これもＢに屬し，B は 60以上で安定なことの證明になると考えられる，線の偪 について觀察すると結晶化の始まり No. 11, No 1 は巾廣 く溫度上昇と〉もに鮮銳になる. 室溫に下げると擴がる

(3) 本誌, B-14(1950), No. 3 .

(4) 山森, 本誌, B-15 (1951), 274. 
が，それは夏理によつてウが鼠なり(No.13,16), 高溫處理 で結晶化が党全であつたもの程擴散の程度が少い(No.13， 16,4,17 を比較). これによつて結晶化の程度を知り，ま た履歷を考慮すればその粒子の大さ怙よび霆を示すものと 思われる. 寸なわち No. 17 の線 4 が 3 に比して廙散し ていることから B が A に變るために B に歪を受けて いると考えられる. しかもその擴散の程度が履歷に影響し ていることから考えると整流器报よび光電菂に扣ける性能 に戀化のあるのはこのような影響む現われて來るのではな い办と考究られる.

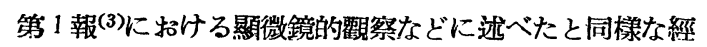
路をたどつてガラス狀セレンは加熱すると結晶化を始め， $40^{\circ}$ で B が出來て成長する. これが白网として認められ たものに相賞する．Ｂは $70^{\circ}$ 以上で安定であるが高溫に括 ける狀態をそのま〉室溫に持ち來たすことは出來ないで盢
度が降るとAに變化する，故に一度結晶化したものは室 溫において A,B の混合である. 故に 2 段處理を $210^{\circ}$ 附 近で行つた整流器括よび光電池では窒溫で不安定な B が 影響を受けるものと考えられる

第 2,3 報に述べた X 線的研究に扣いて求めた格子常數 の值はこの報告における處理を受けた後の室溫に括ける値 に相㖹し，Bの值を測つていたことになる. 著者等の先の 測定の場合 Debye-ring に括いて强度が弱く 1 群の線に 入らないものがあつて保留したものがあるが，これはAに 相當することがわかつた. この A は山森氏の所說(4)によ る單科晶セレンであると思われる.

なお六方晶柔のセレンは螺旋軸を持つた篔狀構造をなと ているのであると考えると，この迎折線の巽常は溫度によ る櫫の積み重ねの葻れによるのかもわからない.これにつ いては今後考察して見たいと思う. 